\title{
The Impact of Biogas Utilization on Poverty in Indonesia
}

Jayanti Maharani ${ }^{1}$ and Djoni Hartono ${ }^{2}$

Corresponding author. Email: djoni.hartono@gmail.com

Submitted: July 27 $2021 \mid$ Accepted: October $23^{\text {rd }} 2021 \mid$ Published: October $31^{\text {st }} 2021$

\begin{abstract}
The provision of reliable, adequate, and sustainable energy services has been a global challenge until today. The un-availability of energy, particularly for cooking and lighting leads to difficulties in achieving the expected quality of life, mainly for underprivileged people who have not met the minimum standard of living. In order to fulfill the necessity of energy, it is necessary to use new renewable energy sources, one of which is through biogas installations. The purpose of this study was to find empirical evidence related to the impact of biogas utilization on poverty, especially in rural areas, by transforming the number of underprivileged people in an area. Through Village Potential (Potensi Desa/Podes) data 2008 - 2018, Biogas development from the Ministry of Energy and Mineral Resources in 2011-2017 and using the difference-in-differences (DID) method, it is expected that this study contributes to the literature, primarily related to energy, with comprehensive results. This study detected that after implementing the biogas installation program, the number of beneficiaries of health insurance programs in villages with biogas installations decreased by 136 people compared to villages without biogas.
\end{abstract}

Keywords: Biogas, DID, Energy, Poverty.

\footnotetext{
${ }^{1}$ Directorate of Electricity, Telecommunications and Informatics, Ministry of National Development Planning/ Bappenas Email: jayanti.maharani@bappenas.go.id

${ }^{2}$ Faculty of Economics and Business, Universitas Indonesia. Email: djoni.hartono@gmail.com
} 


\title{
The Impact of Biogas Utilization on Poverty in Indonesia
}

\author{
Jayanti Maharani and Djoni Hartono
}

\section{Introduction}

The provision of reliable, adequate, and sustainable energy services has been a global challenge until today. Energy is an essential factor in meeting basic requirements such as cooking and lighting, particularly for residents in rural areas (Jana, 2016). However, in reality, not all residents have equal opportunities to obtain energy. There were still many people who did not have access to electricity, which is around 840 million people in 2017. Subsequent data also shows that in 2016 there were nearly 3 billion people spread across Asia and Africa without access to clean cooking solutions (IEA et al., 2019). Energy development in rural areas is related to the improvement of living standards, sustainable environment, and rural economic development. Without energy for cooking and lighting, the community cannot meet the minimum standard of living so that a decent quality of life will be difficult to achieve (Tumiwa and Imelda, 2011), especially for underprivileged people. Poverty itself is an inability of an individual to fulfill the minimum standard of living or an economic inability to meet basic needs.

The utilization of renewable and environmentally friendly energy sources, one of which is through the installation of biogas, can meet the achievement of minimum living standards and improve people's living standards. Biogas is a viable alternative source of biomass-based energy as fuel (Alexopoulos, 2012). Biogas, primarily consisting of methane $\left(\mathrm{CH}_{4}\right)$, can be produced from municipal waste, agricultural waste, and plant material, allows biogas for using in cooking and lighting (Liu et al., 2016). The use of biogas can solve various problems, including energy production, waste management, and social, as well as economic and environmental problems. The transition from conventional energy to biogas possibly increases income (Ali, Rahut, and Behera, 2016). The benefits of biogas in households include the replacement of commercial fuels by biogas, time reduction to collect firewood, and the substitution of chemical fertilizers and pesticides by utilizing the remaining biogas production. Furthermore, the application of biogas might increase income and reduce poverty.

The biogas program in Indonesia provides an opportunity for this research to analyze the impact of biogas utilization primarily in poor rural areas. The Directorate General of New Renewable Energy and Energy Conservation (Energi Baru Terbarukan dan Konservasi Energi/EBTKE) of the Ministry of Energy and Mineral Resources (MEMR) has developed a biogas installation program throughout Indonesia. In addition, the Domestic Biogas (Biogas Rumah/Biru) program, which was an initiative between MEMR and Hivos in 2009, has helped to realize the implementation of biogas technology in Indonesia. As of April 2019, a total of 43,836 units that produce biogas of 74,567.8 $\mathrm{m}^{3}$ gas/day $\sim 25.76$ million $\mathrm{m}^{3}$ gas/year have been developed. Development is carried out through the Biru program, Directorate General of EBTKE, funding from the Specific Allocation Grants (Dana Alokasi Khusus/DAK) for Small-Scale Energy, Ministries/Institutions (Kementerian Lembaga/ K/L) and the private sector (KESDM, 
2019). Hence, Indonesia can be an exciting example to measure the contribution of biogas programs to reduce the number of poverty in this area.

Research that discusses the contribution of the biogas program to poverty alleviation in Indonesia is still minimal. Most of the existing research only discussed the savings felt after using biogas with case studies in one location using the survey method. Research in West Java province shows that the biogas program reduced public spending approximately 1.1 million rupiahs in buying LPG and create new jobs such as processing biogas waste fertilizer to increase community income (Harahap, 2018). Thus, this research is critical to be able to see how far the impact of the biogas program run by the Indonesian government on reducing the number of poor people in rural areas.

In line with that, this research contributes to the existing literature with a case study in Indonesia, which used a total sample of 2,374 villages spread throughout Indonesia and over a more extended period, between 2008-2018, compared to previous research. This study used the difference-in-differences (DID) method to analyze the impact of the biogas program in reducing the number of poor people in a village, especially in rural areas. Villages that possess biogas installations were analyzed as a treatment group, while villages that do not have biogas installations were the control group. This study used data on Village Potential (Potensi Desa/Podes) in 2008, 2011, 2014, and 2018 published by the National Statistics Agency (Badan Pusat Statistik/BPS) and data on the construction of biogas installations in 2011-2017 in various regions in Indonesia from the Directorate General of EBTKE, MEMR. The analysis unit was village level based on Podes data. The weakness of Podes data is that there is no data on the number of poor people and the amount of income of the population. Therefore the poverty data used in this study was based on the number of recipients of the health insurance program provided by the Indonesian government to underprivileged residents (Wirawan, 2019). Data on recipients of health program assistance represented the number of poor residents in a village. The social service office, in collaboration with village officials, regularly collects data and monitors and evaluates the eligibility of beneficiaries to ensure data validation. The impact of the biogas program in poverty alleviation was analyzed by comparing the difference in the number of recipients of health programs between the treatment group and control group in the period before and after the construction of biogas installations.

This study detected that, after the biogas installation construction program, the number of recipients of health insurance programs in villages with biogas installations decreased by 136 people compared to villages that have not installed biogas. The number of recipients of health insurance represented the number of poor people in a village. The results of this study are consistent in a series of tests and pass the assumption of a pretreatment test. This finding can strengthen the construction of biogas installations as an alternative solution to overcome poverty, especially in rural areas. This study complements the literature on the impact of biogas utilization on poverty and can be the basis for implementing evidence-based energy policy.

This research consists of several parts. The second part is a literature review that explains biogas development in Indonesia and existing empirical studies. The third part describes the research methodology, which consists of data sources and analytical methods used in the research. The fourth part is the content consists of a discussion of analysis 
results. The fifth section contains the conclusions of research results and policy recommendations.

\section{Literature Review}

\subsection{Contribution of Bigas to Poverty}

In this study, the main subject was the estimation of poverty level with the utilization of biogas. According to BPS, the measurement of the poverty level uses the ability to meet basic needs (basic needs approach). Poverty is an economic inability to meet basic food and non-food needs as measured from the expenditure side. In addition, the concept of poverty, according to the World Bank, is the inability to achieve a minimum standard of living.

The energy sector plays a vital role in the economic growth and development of a country. The energy sector is a primary sector that becomes the foundation for achieving development goals, such as creating job opportunities, increasing national income, changing the economic structure, and improving people's welfare (Adam, 2012). Sustainable Development Goals (SDGs) goal 7 contains ensuring affordable, reliable, sustainable, and modern energy access for all. The provision of energy access is encouraged by utilizing local energy potential, especially new and renewable energy (NRE). NRE is considered capable of reducing poverty by providing access to energy for underprivileged residents, especially in rural areas, besides encourage sustainable economic growth. The availability of energy, in general, can increase household income and consumption, which can increase regional economic growth in the rural areas. Energy itself is an essential factor to fulfill basic needs such as cooking and lighting, especially for people in rural areas (Jana, 2016). There are many types of new renewable energy sources, but the discussion in this study will use biogas as fuel for cooking and lighting.

Principally, the relationship between biogas utilization and poverty reduction is as follows. The development of energy infrastructure, namely biogas installations, can empower the community, create job opportunities, increase development capacity and create social protection, which is the main factor in reducing poverty. Biogas is renewable energy source derived from biomass for fuel. It consists of 35 percent carbon dioxide $\left(\mathrm{CO}_{2}\right)$ and 65 percent methane $\left(\mathrm{CH}_{4}\right)$. Biogas is produced from raw materials such as livestock waste (cow dung, buffalo, pigs), agricultural waste (liquid tofu waste, tapioca liquid waste), household waste (sewage, sludge, domestic waste), and aquatic plants (seaweed, water hyacinth) (KESDM, 2016). Raw materials processing site called biogas digester. Besides producing gas as an energy source, the by-product produced from the biodigester is slurry, which is an environmentally friendly fertilizer (Bond and Templeton, 2011).

The use of biogas in households, especially in rural areas, is related to the fulfillment of household needs for cooking and lighting, the social structure of the community, and the productivity of small farmers. In rural areas, people use firewood and LPG for cooking and lighting, which requires time and energy to collect firewood that is not environmentally friendly. Therefore, people have to buy LPG. At the national level, the government still face problem regarding the usage of LPG, considering the government has to import LPG to meet national needs and the LPG subsidy policy, which 
become main problems that burden on the state budget. So that with the use of biogas can save expenditure on fuel and the budget transferred to other more productive purposes (Alemayehu, 2015). It can also reduce the government's burden by reducing LPG imports and subsidies. Biogas is also a potential means to improve people's welfare through the use of bio-slurry. Bioslurry is an organic fertilizer that can increase agricultural production, which then increases revenue (Biogas-Cost and Benefits, 2016). Besides being used for their purposes, bioslurry can also be sold in the market to generate additional sources of income. As incomes increase, biogas, especially for poor people, can improve family nutrition and reduce the risk of hunger. Then a snowball effect occurs in which the poor people could improve their living standards and start spending more money on things like household appliances. Local and regional income also increases indirectly from the use of biogas. Therefore, the use of biogas can reduce poverty (Smith, 2011).

\subsection{Biogas Development Program in Indonesia}

The biogas development program in Indonesia is a renewable energy development program following Presidential Regulation (Peraturan Presiden/Perpres) No. 22 of 2017 concerning the General National Energy Plan (Rencana Umum Energi Nasional/RUEN). RUEN is an effort to increase energy independence and security. RUEN has set a renewable energy mix target of 23 percent in 2025 and 31 percent in 2050. In meeting the renewable energy target, the target for bioenergy is 13 percent, or half of the role of renewable energy in 2025, comes from bioenergy. So that it is necessary to utilize the maximum potential of biomass and biogas dissemination throughout Indonesia to support the achievement of these targets (KESDM, 2016), furthermore, biogas development can participate in reducing emission levels in Indonesia. The emission reduction policy following Perpres No. 61 of 2011 concerning the National Action Plan for Reducing Greenhouse Gas Emissions (Rencana Aksi Nasional Gerakan Rumah Kaca/RAN GRK). This policy is also in line with the international focus on energy availability for the community, namely Sustainable Development Goals (SDGs). The focus on energy in the SDGs agenda is the 7th goal, which is to ensure affordable, reliable, sustainable, and modern energy for all. The biogas development can contribute to achieve the energy mix target and reduce emissions by setting a national biogas development target of 489.8 million $\mathrm{m}^{3}$. In 2019 , 43,836 biogas installations were built to produce $74,567.8 \mathrm{~m}^{3}$ of gas/day or 25.76 million $\mathrm{m}^{3}$ /year (KESDM, 2019).

The target of biogas development in Indonesia can overcome several problems in the energy sector. The strategic issues encountered by Indonesia include the high percentage of fossil fuel use in power plants (gas, coal, and oil) reaching 87.68 percent, and not all people have access to electricity, which is 1.7 percent. In fuel for cooking, firewood for cooking in Indonesia is still high at 21.57 percent. Meanwhile, 75 percent of LPG needs for households are still imported from abroad, and the government's LPG subsidy policy is still not on target. The subsidies policy is one of the priority activities to accelerate poverty reduction (Bappenas, 2020). In Indonesia, the raw materials of biogas come from livestock waste, household and urban waste (human waste, industrial and domestic waste), agricultural waste (rice straw), industrial waste (liquid tofu waste, palm oil industrial wastewater / POME, solid tapioca waste) and aquatic plants (water hyacinth and seaweed). 
In general, there are two groups of biogas utilization in Indonesia, namely for cooking in communal and household biogas and as an electricity source, both on-grid and off-grid. The implementation of a biogas development program is carried out and financed by various agencies in Indonesia, namely (i) the MEMR's State Revenue and Expenditure Budget (Anggaran Pendapatan dan Belanja Negaral APBN) for the construction of household-scale biogas until 2015 and the construction of communal biogas in Islamic boarding schools from 2015-2018; (ii) Small-scale Energy DAK financing in the form of household-scale biogas based on a proposal from the Regional Government involving three Ministries namely Bappenas, Ministry of Finance and MEMR. Implementation of Small-Scale Energy DAK until 2018; (iii) the Biru program collaborates between the Government of Indonesia and Netherlands since 2009. The Directorate General of EBTKE and Hivos who run The Biru program. The Biru Program was developed based on research results showing that the potential for household-scale biogas in Indonesia reaches 1 million units and provides financial benefits for farmers. By 2019, the Biru program had built 47 percent of the total biogas installations in Indonesia; (iv) APBN from other Ministries/Institutions other than MEMR and Regional Government Revenue and Expenditure Budget (Anggaran Pendapatan dan Belanja Daerah/ APBD); and (v) Private Parties (KESDM, 2019).

There are several challenges and obstacles encountered during the development of biogas program in Indonesia, including (i) the absence of a national biogas plan such as a sustainable biogas roadmap, (ii) constraints at the production level, including high installation cost and lack of biogas raw materials, such as manure, (iii) the complexity of procedure for using biogas compared to LPG, cause most people are uninterested, and (iv) from a funding perspective, the government's biogas program financing scheme is counterproductive with Non-Governmental Organizations (NGOs). The government assists in grants and total subsidies in most programs, while NGOs use semi-commercial schemes. The subsidies from the government make many people reluctant to buy biogas reactors from NGOs because they are waiting for unrestricted grants from the government (Bappenas, 2019).

\subsection{Empirical Studies}

Various kinds of literature have shown the contribution of biogas utilization to poverty. The application of biogas technology affects the number of underprivileged people in an area through the dimensions of poverty, namely standard/quality of life, education, and health (Smith, 2011). The direct benefit to the community in using biogas is that there is less time and effort to collect firewood, especially for women (Abadi et al., 2016). Women aged between 18-59 years are responsible for the collection and management of energy sources in the household (Gwavuya et al., 2012). Women need approximately 10 hours a week to collect firewood, thereby depriving them of opportunities to engage in other productive activities, saving time for collecting firewood and more time for productive activities because the use of biogas will increase income and standard/quality of life (Dragicevic, Miletic, and Pavkovic, 2015). Firewood could be rare in some areas, so the workload of finding firewood is higher. Women and girls have to walk miles and miles into the forest to collect firewood, which causes some girls to drop out of school, and women spend less time with children and household or outdoor 
activities. With biogas, it needs less time for cooking and could provide lighting at night, allowing spending more time on children's education. Therefore it will improve the family's education level (Dash, Behera, and Rahut, 2018). The direct use of biogas is more beneficial for women than men by reducing their workload with sharing work responsibilities with their spouses (Yasar et al., 2017).

In addition, environmental impacts of biogas are extensive; namely, through the use of a biodigester to accommodate dirt and waste, it can help reduce the number of flies and controlling waste odors (Dragicevic, Miletic, and Pavkovic, 2015), houses become cleaner than before, and the community becomes healthier (SETM, 2014). The application of biogas technology in rural households reduced up to 25 percent of respiratory and cardiovascular diseases. The transition from fuel to alternative energy will improve environmental quality and reduce health risks, increasing health/life expectancy (Yasar et al., 2017).

When the biogas program has been running for more than one year, the benefits become wider. Biogas can be a fundamental driver for developing economic opportunities and increasing household productivity. The transition and shift towards alternative energy such as biogas technology can improve household financial status by increasing income (Ali, Rahut, and Behera, 2016). People can save 3 hours per day of cooking time to generate more income (Yasar et al., 2017). The income is increased, among others, through improving agricultural productivity since the slurry produced from the biodigester becomes a nutrient-rich organic fertilizer for crops (Sawatdeenarunat et al., 2016). Yields from agricultural production increased by 6-10 percent and, in some cases, up to 20 percent (Biogas-Cost and Benefits, 2016). The application of biogas with the installation of a biodigester creates a new opportunity for livelihood because it takes several experts for design, construction work, and other jobs that do not require special skills for daily operations. In Nepal, there was an increase in employment opportunities between 19922004 as many as one million jobs were created in the biogas sector. The positive impact of biogas on the environment is to reduce people's dependence on firewood. In the long term, the availability of biogas dramatically contributes to reducing the number of poverty and increasing economic growth in the region.

\section{Research Methods}

This study used the DID method to observe the treatment group and control group in two time periods. The impact resulting from implementing a program or policy intervention is the difference or deviation from both groups (Sari, 2019). The DID approach in this study to observe the impact before and after the biogas installation on the number of recipients of health insurance programs, as an indicator approach for the poor population, in an area. There are two different groups; namely, the village where the community uses biogas is the treatment group, and the village that does not use biogas is the control group. The control group is the villages that are in the same sub-district as the treatment group. Villages located in one sub-district tend to have similar characteristics, both in terms of geography, economic conditions, the average education level of the population, and the policies accepted by each village. Therefore the matter that 
distinguishes between treatment villages and control villages is policies on applying biogas in the treatment village.

Biogas location shows villages affected by biogas development (treatment observation). Biogas locations have values that vary for each observation (varies across observation) to compare fixed differences between observations. A dummy variable was needed to reflect the year before biogas construction and the year after biogas construction. Therefore, this study uses a biogas year to indicate the start time of applying biogas development policies (post-treatment period). In the observation period, the year biogas value varies to control changes in conditions for each observation. The interaction between biogas location and year biogas in the DID method is needed to describe the impact before and after biogas construction on the number of recipients of the health insurance program in an area.

Apart from biogas development, other factors affect the number of underprivileged people in a village. Factors that influence poverty include job opportunities and social relations between communities. The poor can get out of poverty because of broader job opportunities in the industrial sector and not only in the agricultural sector (Lin, 2018). The influence of social relations in rural communities is analyzed in this study using an indicator approach to collaborative works in the community in the village. The rural location also plays a role in influencing poverty levels. Rural location in remote areas has a positive relationship with poverty levels. Remote rural locations can hinder development (Belcher, Achdiawan, and Dewi, 2015). Poverty is higher in rural areas far from metropolitan areas (Fisher, 2007). This study uses an approach to topography and transportation access to the village to observe the effect of remoteness in rural locations. The availability of educational infrastructure is crucial because poor education is a significant cause of poverty. Peters and Besley (2014) point out that the lack of learning opportunities leads to more children experiencing crisis and poverty in New Zealand. Education is a fundamental way to reduce and eliminate poverty because it can improve the quality of workers comprehensively, help poor people develop the ability to move out of poverty to prevent the transmission of poverty between generations (Wang, Feng, and Zhang, 2016). Utilization of information and communication technology (ICT) has a positive influence on income growth and poverty alleviation. Greater adoption of ICT in low-income groups will accelerate income generation at the base of the economic pyramid (World Economic Forum, 2015). Thus the control variables in this study are the type of work, cooperation habits, village topography, access to transportation to the village, availability of educational infrastructure, and access to media and information in the village such as TV signals and cellphones.

Based on the discussion mentioned above, the fundamental equations of the DID model in this study are as follows :

$$
\operatorname{pov}_{\mathrm{it}}=\beta_{0}+\beta_{1} \text { year_bio }_{\mathrm{it}}+\beta_{2} \text { bio }_{\mathrm{it}}+\beta_{3} \text { year }_{-} b i o_{\mathrm{it}} \times \text { bio }_{\mathrm{it}}+\beta_{4} \text { control }_{\mathrm{it}}+\delta_{\mathrm{t}}+u_{\mathrm{it}}
$$

pov represents the dependent variable related to poverty with data approach the number of recipients of health insurance program assistance from the government in a village $i$ in year t. Year_bio is a dummy year of biogas installation construction in the village i in year $\mathrm{t}$; if the value is 1 then the village in question has been built/there is a construction of a biogas installation, and if the value is o then vice versa. Bio is a dummy location of a village 
that has used biogas; if the value is 1 then the village has used biogas, and if it has a value of 0 then vice versa. Next is the control variable which consists of work is a dummy the main source of income for most of the population comes from the business field in village $\mathrm{i}$ in the period $\mathrm{t}$ year, if it is worth 1 then the main source of income for most of the population in village $i$ comes from agricultural business and if it is worth $o$ then it comes from non-agricultural; communalwork is a dummy of habits and involvement of residents in communal activities in village $\mathrm{i}$ in the period $\mathrm{t}$ year, if it is worth 1 then the village in question has the habit of communal work and if it is worth o then vice versa; topography is a dummy topography in village $i$ in the period of year $t$, if the value is 1 then the village in question is located in a plain area and if the value is 0 then the other; transportation is a dummy access to transportation to the village in village $i$ in the period of year $t$, if the value is 1 then the village can be reached using land transportation, if the value is 0 then other; island is a dummy island in village $i$ in the period $t$ year, if the value is 1 then the village is located on the island of Java, if the value is 0 then it is located outside the island of Java; primaryschool is a dummy of the availability of primary school infrastructure in village $i$ in the period $t$ year, if it is worth 1 then the village in question has school infrastructure available and if it is worth o then vice versa; juniorhighschool is a dummy for the availability of junior high school infrastructure in village $i$ in the year t period, if it is worth 1 then the village in question has school infrastructure available and if it is worth o then vice versa; highschool is a dummy for the availability of high school infrastructure in village $i$ in the year $t$ period, if it is worth 1 then the village has school infrastructure available and if it is worth 0 then there are no high school in the village; TVsignal is a dummy of the availability of television broadcasts (TVRI and/or Regional TVRI) received by village $\mathrm{i}$ in the period $\mathrm{t}$ year, if the value is 1 then the village in question receives TV broadcasts and if the value is $O$ then vice versa; HPsignal is the dummy availability of cellular/mobile phone signals in most areas in village $\mathrm{i}$ in the year t period, if the value is 1 then the village in question has a telephone signal available either weak, strong or very strong and if it is 0 then it does not get a cell phone signal/ mobile phone; $\delta_{t}$ is year effects and $u$ is error term. Year_bio $\mathrm{x}$ bio is the interaction variable between year_bio and bio used in the DID method to describe the impact of biogas use on the number of recipients of the health insurance program in an area.

The coefficient on the interaction variable becomes the focus of DID method application, where the coefficient is a treatment effect. The average difference in outcomes in the treatment group were:

$$
\left(\text { pov }_{\mathrm{i} 2} \mid \text { bio }_{1}=1\right)-\left(\text { pov }_{\mathrm{il}} \mid \text { bio }_{1}=1\right)=\left(\beta_{0}+\beta_{1}+\beta_{2}+\beta_{3}+\beta_{4}\right)-\left(\beta_{0}+\beta_{2}+\beta_{4}\right)=\left(\beta_{1}+\beta_{3}\right)
$$

The average difference in outcomes in the control group were:

$$
\left(\text { pov }_{\mathrm{i} 2} \mid \text { bio }_{1}=0\right)-\left(\text { pov }_{\mathrm{i} 1} \mid \text { bio }_{1}=0\right)=\left(\beta_{0}+\beta_{1}\right)-\left(\beta_{0}\right)=\beta_{1}
$$

The treatment effect is:

$$
\left[\left(\text { pov }_{\mathrm{i} \mid} \mid b_{i o_{1}}=1\right)-\left(\text { pov }_{\mathrm{i} 1} \mid b_{i o_{1}}=1\right)\right]-\left[\left(\text { pov }_{\mathrm{i} \mid} \mid \text { bio }_{1}=0\right)-\left(\text { pov }_{\mathrm{i} 1} \mid b_{i o_{1}}=0\right)\right]=\left(\beta_{1}+\beta_{3}\right)-\left(\beta_{1}\right)=\beta_{3}
$$

This study uses panel data to evaluate individual heterogeneity to eliminate bias. Besides being able to capture differences between individuals, panel data can also compare the conditions of these individuals in one period with other periods. Before implementing the DID method, it is necessary to make a pre-treatment trend assumption to see the 
similarity of trends in the number of recipients between treatment and control groups before policy intervention on the use of biogas. Given the similarity of trends in the two groups before the biogas policy, the difference in trends in the number of recipients of health insurance program assistance that occurred afterward impacted implementing the biogas use policy.

In assessing the pre-treatment trend or parallel trend assumption, this study follows the method introduced by Muralidharan and Prakash (2017) by using the basic model of regression equation as follows:

$$
\operatorname{pov}_{\mathrm{it}}=\beta_{0}+\beta_{1} \text { timerescale }+\beta_{2} \text { timerescale } \times \text { bio }_{\mathrm{it}}+u_{\mathrm{it}}
$$

pov is the number of people who received health insurance program assistance in the village $\mathrm{i}$ in the year t period; timerescale is a dummy time rescale variable for each village, where $O$ is the first year of applying the use of biogas. The year 2011 was used as the first year of applying the use of biogas in this study. The pre-treatment test aims to see if there was a similar trend before 2011. Then $-1,-2,-3$ are the years before implementing the biogas use policy in each village, and 1,2,3 -years after 2011. The data sample used in the pre-treatment test is limited to only the pre-treatment period or the period before the policy (time rescale $<0$ ) and not at the entire sample data (time rescale $>0$ does not include in the pre-treatment test). By using only the time rescale $<0$ can show that there is no difference in the average trend of the number of recipients of the health insurance program between the treatment group and the control group. Bio is a dummy location of a village that has used biogas, if it is worth 1 , then the village has used biogas, and if it is worth 0 then vice versa, and $u$ is the error term. Coefficient 2 will capture the difference in trends in the pre-treatment period (before the policy on the use of biogas) in both the treatment group and the control group. The null hypothesis for 2 is $2=0$. There is a similar trend in the number of recipients of health insurance program assistance in the treatment villages and control villages in the pre-treatment period.

\subsection{Data}

This study uses panel data for analysis. The panel data used are Podes data in 2008, 2011, 2014, and 2018 from BPS and data from MEMR related to the location of biogas installation construction. The unit of analysis used is the village level based on Podes data. Podes data has a weakness; namely there is no data on the number of poor people and the amount of income of the population. So that in this study, data on the number of poor people in the village used data on the number of recipients of health insurance program (Jaminan Kesehatan Masyarakat/ Jamkesmas) in every village in Indonesia as the dependent variable. The data on recipients of Jamkesmas contribution assistance was used as a proxy to evaluate the number of underprivileged people in the village (Wirawan, 2019).

Jamkesmas is a national social assistance program for health services for the poor and underprivileged to realize comprehensive health services. The purpose of Jamkesmas is to guarantee health services for the poor and underprivileged using the principle of social health insurance (Jamkesmas, 2014). However, the use of data on recipients of health insurance programs as an approach to the number of poor people also has drawbacks, namely the inaccuracy of targeting recipients of Jamkesmas contribution assistance. Jamkesmas does not reach the poor population as a whole, and getting Jamkesmas not 
entirely are poor (Lutfiah, Setiawan, and Lucia, 2015). However, the government continues to try to overcome the problem of inaccuracy in aiding recipients. Since 2012, the Ministry of Health has used an integrated database from the National Team for the Acceleration of Poverty Reduction (Tim Nasional Percepatan Penanggulangan Kemiskinan/ $\mathrm{TNP}_{2} \mathrm{~K}$ ) in collaboration with BPS to determine Jamkesmas participation in data collection of the poor (Kementerian Kesehatan, 2012).

In addition, a study conducted in Massachusetts, United States, showed that health insurance benefits could be a component in measuring poverty. This study develops a concept called the Health-Inclusive Poverty Measure (HIPM), which is a measure that includes insurance or health insurance within the poverty threshold. A family could be categorized as inadequate if it cannot meet the basic health insurance needs. The result of this study is that public health insurance assistance and the existence of premium subsidies from the government can reduce the poverty rate inclusive of health by one-third (Korenman, Remler, and Hyson, 2020). Based on these considerations, this study continues to use data on recipients of health insurance programs to describe the number of poor people in rural areas in Indonesia.

Besides using Podes data from BPS, this study also used data on the location of biogas construction from the MEMR as data for the main independent variables in the research model. The data referred to was biogas construction built from 2011 to 2017 in various locations throughout Indonesia through the financing of the MEMR APBN and Small-Scale Energy DAK. However, not all biogas installations in the data are research samples due to the lack of detailed information regarding the location of biogas construction. In addition, due to data limitations, this study only used a sample of biogas construction sites financed by the APBN MEMR and Small-Scale Energy DAK. The types of biogas installations in this study in the treatment village were household biogas with an average capacity of $17 \mathrm{~m}^{3}$ gas/day with ten recipients being the recipients, communal biogas at Islamic boarding schools with an average capacity of $5.4 \mathrm{~m}^{3}$ gas/day with recipients 1,000 people and communal biogas from industrial tofu waste with an average capacity of $16.1 \mathrm{~m}^{3}$ of gas/day with nine beneficiary households. Given that there is a limitation in this study that does not consider the number of biogas installations in one village.

As mentioned in the previous section, the biogas development program in Indonesia is implemented and financed by various other agencies, namely through the Biru program, APBN from other Ministries/Institutions besides MEMR, Regional Government budget, and private parties. Biogas installations built through the MEMR and DAK are 25 percent, and the Biru program is 47 percent, and the rest is through other financings. The biogas development in Indonesia was carried out based on the type of implementation, namely non-commercial, semi-commercial, and commercial. The noncommercial approach is carried out through a funding scheme financed by APBN and DAK. Its implementation in areas where there is no biogas development to provides direct examples to the community. The semi-commercial approach uses a partial subsidy scheme, in which the program amount is only partially subsidized, and the rest is pursued by residents. The semi-commercial approach aims to increase the sense of ownership and ensure the sustainability of the program. It is a continuation of the pilot stage by 
combining community capabilities and responsibilities. The example of a semi-commercial approach was the implementation of the Biru program (KESDM, 2016). Therefore, the Biru program is a continuation of a biogas development program through the APBN and DAK also carries out biogas development in the exact location as the sample data. With this assumption, the recipients of biogas installations in the sample villages will increase. Meanwhile, the location for biogas construction from the Biru program, which has a different location for biogas from the APBN and DAK, is not the sample data in this study.

Based on this consideration, there were 459 villages in various locations throughout Indonesia that possess biogas installations as the data in this study -then combined the locations of biogas installations in various villages with Podes data from BPS. Therefore, the total sample villages in this study were 2,374 villages, in which 459 villages were the treatment group and 1,915 villages were the control group.

Table 1. Table of Sample Village Characteristics

\begin{tabular}{lcccc}
\hline & \multicolumn{2}{c}{$\begin{array}{c}\text { Treatment Village } \\
(\mathbf{n = 4 5 9 )}\end{array}$} & \multicolumn{2}{c}{$\begin{array}{c}\text { Control Village } \\
(\mathbf{n = 1 9 1 5})\end{array}$} \\
& 2008 & 2018 & 2008 & 2018 \\
\hline $\begin{array}{l}\text { The existence of households } \\
\text { without electricity }\end{array}$ & $13.74 \%$ & $1.36 \%$ & $12.12 \%$ & $1.77 \%$ \\
Cooking fuel & & & & \\
$\quad$ LPG & $0.87 \%$ & $79.30 \%$ & $2.4 \%$ & $84.54 \%$ \\
$\quad$ Kerosene & $24.40 \%$ & $5.45 \%$ & $28.09 \%$ & $3.24 \%$ \\
$\quad \begin{array}{l}\text { Firewood } \\
\text { Public street lighting }\end{array}$ & $73.86 \%$ & $15.25 \%$ & $66.78 \%$ & $12.11 \%$ \\
Asphalt roads & $83.00 \%$ & $89.76 \%$ & $77.39 \%$ & $88.20 \%$ \\
Throwing garbage in the trash & $75.38 \%$ & $89.32 \%$ & $66.74 \%$ & $84.44 \%$ \\
Sanitation with own latrines & $1.31 \%$ & $11.76 \%$ & $1.88 \%$ & $12.27 \%$ \\
\hline
\end{tabular}

Source-: BPS processed, 2021

Table 1 shows the characteristics of the sample villages, both treatment villages and control villages, at the beginning and end of this study. At the beginning of this study, villages that used biogas have regional characteristics that were more lagging than nonbiogas villages. The percentage of households without electricity was higher at 13.74 percent. The utilization of firewood for cooking was higher at 73.86 percent. At the end of this study, after the biogas utilization program, the characteristics of the biogas village area were more advanced than the non-biogas villages. The presence of households without electricity was reduced by 1.36 percent. The use of firewood was also reduced by 15.25 percent. Based on Table 1, the development of public infrastructure has been going on throughout Indonesia, such as increasing the number of public street lighting and asphalt road access as transportation access between regions. In addition, public awareness to dispose of waste in the trash and use sanitation with their latrines can implement biogas use in rural communities.

\section{Results and Discussion}

This study aims to see the impact of biogas installation programs on the number of recipients of health insurance programs which describes the number of poor people. The 
initial discussion of the research results is related to testing the pre-treatment trend assumption, which was the initial assumption of using the DID method. After that, testing equation (1) to observe the impact of biogas installations construction on the number of recipients of a health insurance program, which is the fundamental equation of the model, followed by an explanation of the estimation results of the fundamental equation and robustness check which aims to analyze the consistency of the equation (1).

\subsection{Descriptive Statistics}

Descriptive statistics is a collection and ranking of data to describe the characteristics of the sample used in this study. These statistics explain the characteristics of the sample as follows (i) the mean value, namely the average value of each variable, (ii) extreme values, namely the minimum or lowest value and the maximum or highest value for each variable in the study, and (iii) standard deviation which is the distribution of the data used in this study which reflects the heterogeneous or homogeneous data that fluctuates in nature. The descriptive statistics of the research variables are contained in Table 2 .

Table 2. Summary Statistics

\begin{tabular}{lccccc}
\hline \multicolumn{1}{c}{ Variabel } & Obs & Min & Mean & Max & Std. Dev \\
\hline pov & 9.496 & 0 & 1001,88 & 99.999 & 1788,71 \\
year_bio & 9.496 & 0 & 0,33 & 1 & 0,47 \\
bio & 9.496 & 0 & 0,19 & 1 & 0,39 \\
year_bio x bio & 9.496 & 0 & 0,07 & 1 & 0,25 \\
timerescale & 9.496 & -9 & $-1,48$ & 7 & 3,99 \\
work & 9.496 & 0 & 0,93 & 1 & 0,26 \\
communalwork & 9.496 & 0 & 0,75 & 1 & 0,43 \\
topography & 9.496 & 0 & 0,74 & 1 & 0,44 \\
transportation & 9.496 & 0 & 0,97 & 1 & 0,16 \\
island & 9.496 & 0 & 0,47 & 1 & 0,50 \\
primaryschool & 9.496 & 0 & 0,93 & 1 & 0,26 \\
juniorhighschool & 9.496 & 0 & 0,47 & 1 & 0,50 \\
highschool & 9.496 & 0 & 0,24 & 1 & 0,43 \\
TVsignal & 9.496 & 0 & 0,85 & 1 & 0,36 \\
HPsignal & 9.496 & 0 & 0,99 & 1 & 0,10 \\
\hline
\end{tabular}

Source-: Processed data, 2021

Based on Table 2, the number of observations studied was 9,496 samples consisting of 2,374 villages over four years, resulting in a strongly balanced for the data panel with about 19 percent of which were biogas villages symbolized by the bio variable as much as 459 villages. The average dependent variable, namely pov, was 1001.88. The minimum pov value was 0 , which means that the villages did not receive the Jamkesmas program contribution assistance at all, and the maximum value is 99,999 people. The standard deviation of 1788.71 shows the maximum increase in the average pov variable was +1788.71 , while the maximum decrease from the average variable was -1788.71 . The time rescale variable in the pre-treatment test only used sample data with a time rescale value of $<0$. The total sample data used in this study resulted in the maximum time rescale value of 7 . 
The main types of work in the sample data are farmers, who account for 93 percent. Likewise, social conditions in rural areas are still intertwined with the habit of cooperation in the community as much as an average of 75 percent of this study sample. The sample villages located on the island of Java were 47 percent, and the rest were outside Java. Public infrastructure shows that the development has been entirely satisfactory in rural areas in Indonesia. As many as 97 percent of villages have access to transportation to the village by land. It has also shown an adequate development in telecommunications, informatics, and communication infrastructure in the sample villages of this study, where TV signals and cellphone signals have reached 85 percent and 99 percent of rural areas, respectively. As previously discussed, this research encountered a selection problem, one of which is selecting locations for the distribution of biogas programs from the government, which requires a feasibility study document to ensure project sustainability. This is in line with the data in this study that, in general, the characteristics of the sample rural areas support the construction of biogas installations in the countryside, both from the type of community work, cooperation social relations, the availability of transportation access, and information media for the socialization of biogas technology. They aimed to improve the community's welfare, especially for the people who live below the poverty line. The existence of supporting facilities leads the village tends to be able to prepare a good biogas installation feasibility study, compared to other rural locations that are more lagging behind, and obtained assistance from the government for the construction of a biogas installation.

On the other hand, the existence of educational infrastructure in the sample villages of this study was still limited, especially for junior and senior high schools, which were still below $50 \%$. This shows that the level of education in rural areas is still low; therefore it can worsen the poverty status in these rural areas.

\subsection{Pre-treatment Test}

The pre-treatment test was carried out to observe the similarity of trends between treatment villages and control villages regarding the number of recipients of the health insurance program before the policy. If the trend is proven not to differ significantly, it can be assumed that the characteristics between the treatment villages and control villages during the observation period are identical. With these identical village characteristics, it can be concluded that if there is no intervention/policy treatment, the two groups will have the same trend in the number of recipients of the health insurance program. In other words, the pre-treatment test is met.

The assumptions in the pre-treatment test are the basic assumptions of the DID method. The pre-treatment test was carried out by regressing equation (5). The data sample used in the pre-treatment test was limited only during the pre-treatment period or the period before the policy (time rescale $<0$ ), which showed no difference in the average trend of the recipients' number of health insurance program assistance between the treatment group and the control group. Variable time rescale $=0$ was set as the first year of implementing the biogas installation development policy. The results of the pretreatment test are presented in Table 3. 
Table 3. Test Results of Pre-treatment Test

\begin{tabular}{lc}
\hline $\begin{array}{l}\text { Dependent Variable: The number of recipients of } \\
\text { the health insurance program }\end{array}$ & $\begin{array}{l}\text { Pre-treatment } \\
\text { coefficient }\end{array}$ \\
\hline Independent Variable : & $44.95 * * *$ \\
timerescale & $(5.02)$ \\
& 22.59 \\
timerescale x bio & $(13.77)$ \\
& 5,642 \\
Observations & 2,374 \\
Number of Villages & \\
\hline
\end{tabular}

Note : Confidence level $99 \%(* * *), 95 \%(* *), 90 \%(*)$. Robust standard errors in brackets.

Source- $\quad$ : Data processed, 2021

In Table 3, it is shown that the coefficient of timescale $\mathrm{x}$ bio variable was not significant. This strengthens the justification, which mentioned that the pre-treatment test was fulfilled in the sample of this study; therefore, the DID method can be carried out, and the results were robust. Given the similarity of trends before implementing the biogas installation development policy, the difference in trends of treatment group and control group after the implementation of the biogas utilization policy was the effect of biogas utilization.

\subsection{The Effect of Biogas Installation on the Number of Recipients of Health Insurance Program}

Hypothesis testing is done through panel data regression. Panel data regression was carried out using equation (1), with the regression results shown in Table 4. In column (1), only the basic model was used, namely regression with bio, year_bio, and year_bio $\times$ bio. In column (2), control variables were added that describe the economic and social conditions. In column (3), the regression was performed by adding the topographic characteristics, remoteness of villages and islands. Then in column (4), all control variables were analyzed by adding the availability of education and telecommunications, and informatics infrastructure. Table 4 shows that the coefficient value of the interaction variable year_bio $\times$ bio $\left(\beta_{3}\right)$ was negative, namely in column (1) of -147.62 column (2) of -144.14 column (3) of -133.77 and in column (4) is -136.10 , which is entirely significant at the 10 percent level. The interaction coefficients in columns (1), (2), (3), and (4) consistently had a negative sign indicating that on average, after the biogas utilization program was operated, the trend of recipients number of health insurance assistance programs in villages with affected by the biogas policy is lower when compared nonbiogas villages. The interaction coefficients in columns (1), (2), (3), and (4) show that on average, after the biogas utilization program runs, the trend of increasing the number of recipients of the health insurance assistance program in villages affected by the biogas policy was reduced by 148 people, 144 people, 134 people, and 136 people when compared to villages that were not affected by the biogas utilization policy.

Table 4. The Impact of Biogas Installation on The Number of Recipients of Health Insurance Program

\begin{tabular}{lcccc}
\hline $\begin{array}{l}\text { Dependent Variable : The number of } \\
\text { recipients of the health insurance }\end{array}$ & Basic & The & The & The \\
program & Model & with & Model & Model \\
& & with & with
\end{tabular}




\begin{tabular}{|c|c|c|c|c|}
\hline & (1) & $\begin{array}{c}\text { Control } \\
\text { Variable } \\
(2) \\
\end{array}$ & $\begin{array}{c}\text { Control } \\
\text { Variable } \\
(3) \\
\end{array}$ & $\begin{array}{c}\text { Control } \\
\text { Variable } \\
(4) \\
\end{array}$ \\
\hline $\begin{array}{l}\text { Variabel Independen } \\
\text { year_bio x bio }\end{array}$ & $\begin{array}{c}-147.62^{*} \\
(76.95)\end{array}$ & $\begin{array}{c}-144.14^{*} \\
(76.82)\end{array}$ & $\begin{array}{l}-133.77^{*} \\
(77.10)\end{array}$ & $\begin{array}{c}-136.10^{*} \\
(76.16)\end{array}$ \\
\hline year_bio & $\begin{array}{c}125.40^{* * *} \\
(48.68)\end{array}$ & $\begin{array}{c}126.14^{* * *} \\
(48.65)\end{array}$ & $\begin{array}{l}21.00 \\
(52.43)\end{array}$ & $\begin{array}{l}11.13 \\
(52.83)\end{array}$ \\
\hline bio & $\begin{array}{c}257.09^{* * * *} \\
(44.16)\end{array}$ & $\begin{array}{c}256.25^{* * * *} \\
(44.38)\end{array}$ & $\begin{array}{c}238.67 * * * \\
(43.31)\end{array}$ & $\begin{array}{c}174.55^{* * * *} \\
(42.92)\end{array}$ \\
\hline work & & $\begin{array}{r}-90.44^{*} \\
(52.88)\end{array}$ & $\begin{array}{l}-36.95 \\
(55.27)\end{array}$ & $\begin{array}{c}61.22 \\
(64.16)\end{array}$ \\
\hline communalwork & & $\begin{array}{l}71.59^{* * *} \\
(25.26)\end{array}$ & $\begin{array}{l}13.53 \\
(27.58)\end{array}$ & $\begin{array}{c}3.26 \\
(26.56)\end{array}$ \\
\hline topography & & & $\begin{array}{c}7.07 \\
(38.03)\end{array}$ & $\begin{array}{c}12.16 \\
(29.91)\end{array}$ \\
\hline transportation & & & $\begin{array}{l}213.02^{* * * *} \\
(51.15)\end{array}$ & $\begin{array}{c}266.86^{* * * *} \\
(50.40)\end{array}$ \\
\hline island & & & $\begin{array}{l}452.36 * * * 6 \\
(43.25)\end{array}$ & $\begin{array}{l}368.33 * * * * \\
(50.68)\end{array}$ \\
\hline primaryschool & & & & $\begin{array}{c}460.72^{* * * *} \\
(30.16)\end{array}$ \\
\hline juniorhighschool & & & & $\begin{array}{c}267.00^{* * * *} \\
(31.65)\end{array}$ \\
\hline highschool & & & & $\begin{array}{c}236.05^{* * *} \\
(88.27)\end{array}$ \\
\hline TVsignal & & & & $\begin{array}{l}23.75 \\
(39.45)\end{array}$ \\
\hline HPsignal & & & & $\begin{array}{l}31.73 \\
(81.42)\end{array}$ \\
\hline Observations & 9,496 & 9,496 & 9,496 & 9,496 \\
\hline R-squared & 0.017 & 0.017 & 0.034 & 0.053 \\
\hline Number of Villages & 2,374 & 2,374 & 2,374 & 2,374 \\
\hline
\end{tabular}

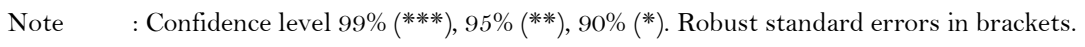

Source- $\quad$ : Data processed, 2021

This finding shows that the biogas installation program had an impact on reducing the average number of recipients of health insurance programs in villages that have biogas installations when compared to villages that do not have biogas, where the number of recipients of health insurance program represented the number of low-income household in the rural area. Thus, the number of underprivileged people in villages that possess has decreased compared to villages that do not have biogas after constructing biogas installations.

This result is in line with the theoretical review, which stated that the application of biogas could reduce poverty (Smith, 2011). Poverty, which is seen as an inability to achieve a minimum standard of living, can be overcome, one of which is through the Indonesian government's policy in the energy infrastructure development program in the form of biogas installations. Biogas can meet basic needs such as cooking and lighting, especially for people in rural areas (Jana, 2016). The use of biogas can substitute for LPG for cooking, and by-product in the form of bio-slurry can be used as an environmentally friendly fertilizer (Bond, 2011).

It is expected that installing biogas will possibly increase community income (Alemayehu, 2015). This objective will be achieved by increasing agricultural production 
due to bio-slurry (Biogas-Cost and Benefits, 2016) and the reallocation of time used for productive activities (Putra, Liu, and Lund, 2017). In addition, the application of biogas for a low-income household can save expenditure on fuel for cooking and lighting (Gwavuya et al., 2012).

\section{Conclusions and Recommendations}

\subsection{Conclusions}

To achieve the minimum standard of living and increase the standard of living of the community can be carried out by fulfilling energy, one of which is through the construction of biogas. Biogas as an alternative energy source can be used by rural communities for cooking and lighting activities. The application of biogas might increase household income through saving on energy expenditure and increasing agricultural productivity due to the use of bio-slurry fertilizer. In the long term, biogas could be used as poverty reduction mitigation.

This study shows that the application of biogas installation program policies had a positive impact on poverty reduction in rural areas. Commonly, after the biogas installation program started, the number of recipients of health insurance programs in villages with biogas installations was 136 people lower than in villages without biogas installations, and this result was significant at the level of 10 percent. These results are in line with previous research conducted in Indonesia. However, the existing research is only in the form of case studies in one district location or even in one village using the survey method, and still limited. In this study, the DID method was used to observe the impact of the biogas program in reducing the number of poor people in rural areas in Indonesia based on Podes data in 2008, 2011, 2014, and 2018 from BPS as well as data on the construction of biogas installations built in various regions in Indonesia from MEMR during 2011-2017. Before identifying the impact of biogas use on the number of recipients of health insurance programs using the DID method, a pre-treatment trend assumption was made to see the similarity of trends in the number of recipients between treatment and control groups before policy intervention on biogas use. By using more significant number of samples (2,374 villages spread throughout Indonesia) and in more extended period (2008 - 2018), it can be concluded that the results of this study are more comprehensive than previous studies.

Finally, some significant limitations to this study need to be considered. First, this research model did not consider the differences in the number of biogas installations in each village. Second, villages with installed biogas, whether only one or more, were included in the category of treatment villages. It is recommended that further research be undertaken in these limited areas for improvement.

\subsection{Recommendations}

There are some critical recommendations and policy interventions from the results of this study that need to be made. First, to improve integration between stakeholders by identifying the roles and authorities of multi-stakeholders (government and nongovernment) and community involvement (public consultation meetings) so that risk mitigation can be anticipated, and the sustainability of biogas projects is guaranteed. 
Second, to develop program synchronization and institutional synergy including Holistic, Integrative, Thematic, Spatial (HITS), and money follows programs - through (a) the funding framework; (b) regulatory framework; and (c) a framework for public services and investment which integrated with financing: including regional transfers and synergies with non-APBN (BUMN) financing. Third, to prepare a sustainable biogas roadmap.

\section{References}

Abadi, N., et al. (2016). Links between biogas technology adoption and health status of households in rural Tigray, Northern Ethiopia. Energy Policy, 101: 284-292. https://doi.org/10.1016/j.enpol.2016.11.015

Adam, L. (2012). The Roles and Problems of Infrastructure in Indonesia. Economics and Finance in Indonesia, 60 (1): 105-126.

Alemayehu, Y. A. (2015). Status and Benefits of Renewable Energy Technologies in the Rural Areas of Ethiopia: A Case Study on Improved Cooking Stoves and Biogas Technologies. International Journal of Renewable Energy Development, 4(12). https://doi.org/10.14710/ijred.4.2.103-111

Alexopoulus, S. (2012). Biogas systems: basics, biogas multifunction, principle of fermentation, and hybrid application with a solar tower for the treatment of waste animal manure. Journal Eng Sci Tech Rev, 5.

Ali, A., Rahut, D. B. \& Behera, B. (2016). Factors influencing farmers' adoption of energybased water pumps and impacts on crop productivity and household income in Pakistan. Renewable and Sustainable Energy Reviews, 54: 48-57. https://doi.org/10.1016/j.rser.2015.09.073

Bappenas. (2019). Pemanfaatan Biogas Nasional.

Bappenas. (2020). Peraturan Presiden Nomor 18 Tahun 2020 tentang Rencana Pembangunan Jangka Menengah Nasional Tahun 2020-2024.

Belcher, B., Achdiawan, R. \& Dewi, S. (2015). Forest-Based Livelihoods Strategies Conditioned by Market Remoteness and Forest Proximity in Jharkhand, India. World Development, 66: 269-279. https://doi.org/10.1016/j.worlddev.2014.08.023

Biogas-Cost and Benefits. (2016). In Energypedia. https://energypedia.info/wiki/Biogas__Costs_and_Benefits

Bond, T. and Templeton, M. R. (2011). History and future of domestic biogas plants in the developing world. Energy for Sustainable development, 15(4): 347-345. https://doi.org/10.1016/.esd.2011.09.003

Dash, M., Behera, B. \& Rahut, D. B. (2018). Understanding the factors that influence household use of clean energy in the Similipal Tiger Reserve, India. National Resource Forum, 42(1): 3-18. https://doi.org/10.1111/1477-8947.12140

Dragicevic, V., Miletic, M. \& Pavkovic, B. (2015). Investigation on possibilities for biogas production from organic waste on the Croatian island of Krk. Tehnicki Vjesnik, 22(3): 755-762.

Gwavuya, S. G., et al. (2012). Household energy economics in rural Ethiopia: A costbenefit analysis of biogas energy. Renewable Energy, 48: 202-209.

Harahap, F. I. (2018). Dampak pemberdayaan masyarakat melalui program biogas dalam mewujudkan kemandirian energi. Jurnal Pendidikan dan Pemberdayaan Masyarakat, $5(1): 41-50$. 
IEA, IRENA, UNSD, WB \& WHO. (2019). Tracking SDG 7: The Energy Progress Report 2019. Washington DC.

Jana, C. (2016). Sustainable domestic lighting options for poor people - an empirical study. Environ Dev Sustain, 18: 1559-1573. https://doi.org/10.1007/s10668-015-9702-6

Kementerian Energi dan Sumber Daya Mineral. (2016). Biogas: Mengolah Limbah Jadi Berkah.

Kementerian Energi dan Sumber Daya Mineral. (2019). Overwiew Program Pengembangan Biogas.

Kementerian Kesehatan Republik Indonesia. (2012). Data Base Terpadu Sasaran Jamkesmas dari TNP2K. https://www.kemkes.go.id/article/view/1930/data-base-terpadusasaran-jamkesmas-dari-tnp2k.html

Kementrian Kesehatan Republik Indonesia. (2014). Jamkesmas. https://www.kemkes.go.id/article/print/13010200021/jamkesmas.html

Korenman, S., Remler, D. K. \& Hyson, R. T. (2020). Health insurance and poverty of the older population in the United States: The importance of a health inclusive poverty measure. The Journal of the Economics of Ageing, 18: 100297. https://doi.org/10.1016/j.jeoa.2020.100297

Liu, Z., et al. (2016). Improved bulk density of bamboo pellets as biomass for energy production. Renewable Energy, 86: 1-7.

Lutfiah, U., Setiawan, E. \& Lucia, S. S. (2015). Ketidaktepatan Sasaran Jaminan Kesehatan Masyarakat Berdasarkan Kriteria Miskin Pendataan Program Perlindungan Sosial. Jurnal Kesehatan Masyarakat Nasional, 9 (4).

Muralidharan, K. and Prakash, N. (2017). Cycling to School Increasing Secondary School Enrollment for Girls in India. American Economic Journal: Applied Economics, 9(3): 321-350. https://doi.org/10.1257/app.20160004

Peters, M. A. and Besley, T. A. (2014). Children in Crisis: Child Poverty and Abuse in New Zealand. Journal Educational Philosophy and Theory, 46(9): 945-961.

Putra, A. R. S., Liu, Z. \& Lund, M. (2017). The impact of biogas technology adoption for farm households-Empirical evidence from mixed crop and livestock farming systems in Indonesia. Renewable and Sustainable Energy Reviews, 74: 1371-1378. https://doi.org/10.1016/j.apenergy.2010.05.011

Sari, A. P. (2019). Pengaruh Remitansi Terhadap Perbedaan Kesejahteraan Rumah Tangga Di Indonesia Dengan Metode Prospensity Score Matching. Jurnal Ekonomi Pembangunan, 8(2): 2302-9595.

Sawatdeenarunat, C., et al. (2016). Anaerobic biorefinery: Currents status, challenges, and opportunities. Bioresource Technology, 215: 304-313. https://doi.org/10.1016/j.biortech.2016.03.074

Smith, J. U. (2011). The Potential of Small-Scale Biogas Digesters to Alleviate Poverty and Improve Long Term Sustainability of Ecosystem Services in Sub-Saharan Africa. Presented in Interdisciplinary Expert Workshop - Addis Ababa University. Ethiopia: 16-18 May 2011.

Sustainable Energy and Technology Management (SETM). (2014). Final report on Study on socio-economic impact of Biogas Support Programme in Nepal. Nepal: Kathmandu.

Tumiwa, F. and Imelda, H. (2011). Kemiskinan Energi Fakta-fakta yang ada di masyarakat Indonesia. Indonesia: IESR. 
Wang, J., Feng, Q. \& Zhang, J. (2016). Education and targeted poverty reduction. Educational Research, 7: 12-21.

Wirawan, H. (2019). Dampak Program Elektrifikasi Off-Grid Berbasis Energi Baru Terbarukan Terhadap Kemiskinan di Indonesia. Unpublished Magister thesis. Indonesia: Universitas Indonesia.

World Economic Forum. (2015). The Global Information Technology Report 2015: ICTs for Inclusive Growth.

Yasar, A., et al. (2017). Socio-economic, health and agriculture benefits of rural household biogas plants in energy scarce developing countries: A case study from Pakistan. Renewable Energy, 108: 19-25. 